\title{
TRAIT PECULIARITIES OF DIABETIC RETINOPATHY INDIVIDUALS
}

\author{
Дроздов В. О., Сакович В. М., Сакович Є. М., Фокіна С. М. Особливості характеру \\ осіб $з$ діабетичною ретинопатією.
}

Метою дослідження було вивчення особливостей характеру хворих із проліферативною та непроліферативною стадіями діабетичної ретинопатії.

Відкритим контрольованим дослідженням було охоплено 30 хворих із діабетичною ретинопатією, з них: у 12 і 18 було діагностовано цукровий діабет I і II типу, у 20 осіб діагностовано непроліферативну стадію діабетичної ретинопатії, у 10 - проліферативну.

Особливості характеру осіб з діабетичною ретинопатією визначено за методикою Р. Кетелла.

Усім хворим з діабетичною ретинопатією були притаманні незалежність, підозрілість, тривожність, невпевненість, заклопотаність, боязкість, недостатня мотивація, самовпевненість, консерватизм, дисциплінованість.

Особливостями характеру пацієнтів 3 непроліферативною діабетичною ретинопатією були безтурботність, підозрілість, незалежність, нечутливість. Конфліктність, розвинений самоконтроль, самовпевненість, консерватизм, низька мотивація, скептицизм, ригідність мислення. Найвиразнішими в них були консерватизм, сумніви щодо нових ідей, скептицизм, цинізм, прагматизм; менш виразними - замкнутість, недовіра, обмежене мислення, труднощі щодо засвоєння нового матеріалу, низька мотивація, лінощі, незворушність, схильність до усвідомленого дотримання норм, бажання уявити себе «у вигідному світлі».

До особливостей характеру осіб з проліферативною діабетичною ретинопатією можна зарахувати підозрілість, самовпевненість, розвинений самоконтроль, відповідальність, консерватизм, самовпевненість, тривожність, роздратованість, песимізм. Найвиразнішими у них були консерватизм, сумніви щодо нових ідей; менш виразними - замкненість, недовіра, обмежене мислення, труднощі в засвоєнні нового матеріалу, низька толерантність до емоціогенних чинників, невпевненість у собі, роздратованість, часті прояви хвилювання, підвищена обережність, розсудливість, стриманість, іноді песимізм, сировість, виразна сором'язливість, боязкість, обережність, перевага вузького кола людей, надмірна самовпевненість, цинізм, прагматизм, лінощі.

Перспективами подальших досліджень є необхідність вивчення впливу емоційних, мотиваційних та інтелектуальних особливостей хворих з діабетичною ретинопатією та їх впливу на якість життя та формування комплайєнсу.

Ключові слова: хворі, діабетична ретинопатія, проліферативна, непроліферативна, характер

Дроздов В. А., Сакович В. Н., Сакович Е. Ф., Фокина С.Н. Характерологические особенности лиц с диабетической ретинопатией

Целью исследования было изучение особенностей характера у больных с пролиферативной и непролиферативной стадией диабетической ретинопатии.

В открытое контролируемое исследование были включены 30 больных с диабетической ретинопатией, из них: 12 и 18 больных с сахарным диабетом I и II типа; у 20 лиц диагностирована непролиферативная стадия диабетической ретинопатии, у 10 пролиферативная.

Особенности характера лиц с диабетической ретинопатией охарактеризованы по методике Р. Кеттелла. 
Всем больным с диабетической ретинопатией были присущи независимость, подозрительность, тревожность, неуверенность, озабоченность, робость, недостаточная мотивация, самоуверенность, консерватизм, дисциплинированность.

Особенностями характера пациентов с непролиферативной диабетической ретинопатией были беспечность, подозрительность, независимость, бесчувственность, конфликтность, развитый самоконтроль, самоуверенность, черствость, консерватизм, низкая мотивация, скептицизм, ригидность мышления. Наиболее выраженными у них были консерватизм, сомнения относительно новых идей, скептицизм, цинизм, прагматизм; менее выраженными - замкнутость, недоверие, ограниченное мышление, сложности в освоении нового материала, низкая мотивация, лень, невозмутимость, склонность к осознанному соблюдению норм, желание представить себя «в выгодном свете».

К особенностям характера лиц с пролиферативной диабетической ретинопатией можно отнести подозрительность, самоуверенность, развитый самоконтроль, ответственность, консерватизм, самоуверенность, тревожность, раздражительность, пессимизм. Самыми выразительными у них были консерватизм, сомнения относительно новых идей; умеренными - замкнутость, недоверие, ограниченное мышление, сложности в освоении нового материала, низкая толерантность к эмоциогенным факторам, неуверенность в себе, раздражительность, частое проявление волнения, повышенная осторожность, рассудительность, сдержанность, иногда пессимизм, суровость, выраженная застенчивость, робость, осторожность, предпочтение узкого круга близких друзей, излишняя самоуверенность, циничность, прагматизм, низкая мотивация, лень.

Перспективой дальнейших исследований является необходимость изучения влияния эмоциональных, мотивационных и интеллектуальных особенностей больных с диабетической ретинопатией и их влияние на качество жизни и формирование комплайенса.

Ключевые слова: больные, диабетическая ретинопатия, пролиферативная, непролиферативная, характер

\section{Drozdov , V. Sakovych , I. Sakovych , S. Fokina. Trait peculiarities of diabetic retinopathy individuals}

The purpose of the research was to study proliferative and non-proliferative retinopathy diabetes' traits.

It was examined 30 diabetic retinopathy patients (Type I - 12 persons and Type II -18 persons) during an open-label controlled study. 20 patients were diagnosed with a non-proliferative stage of diabetic retinopathy, and 10 patients were diagnosed with a proliferative stage.

The peculiarities of retinopathy diabetes' traits were determined by the method of R. Ketell.

All diabetic retinopathy patients were characterized by independence, suspicion, anxiety, uncertainty, concern, timidity, lack of motivation, self-confidence, conservatism, discipline.

Non-proliferative diabetic retinopathy patients' traits were carelessness, suspicion, independence, insensitivity, conflict, developed self-control, self-confidence, callousness, conservatism, low motivation, skepticism, rigidity of thinking. The serious problems for these individuals were their conservatism, doubts about new ideas, skepticism, cynicism, pragmatism; the moderate ones were seclusion, distrust, silo mentality, difficulty in mastering new material, low motivation, laziness, ease, a tendency to comply with the rules, the desire to introduce oneself "in a favourable position".

The leading traits of proliferative diabetic retinopathy people were suspicion, self-confidence, developed self-control, responsibility, conservatism, self-confidence, anxiety, irritability and pessimism. Conservatism and doubts about new ideas were the most difficult problems for these individuals; the moderate ones are seclusion, distrust, silo mentality, difficulty in mastering new material, low tolerance for emotional factors, self-doubt, irritability, frequent manifestation of excitement, increased caution, discretion, restraint, sometimes pessimism desire to be in the shadows, preference for a limit of close friends, excessive self-confidence, subjectivism, hypertrophied desire for independence, stubbornness, skepticism, sometimes cynicism, pragmatism, low motivation and laziness. 
Prospects for further research are the need to determine the impact of emotional, motivational and intellectual characteristics of diabetic retinopathy patients and their impact on quality of life and the formation of compliance.

Key words: patients, diabetic retinopathy, proliferative, non-proliferative, trait

Problem Statement. Diabetes is a major public health problem affecting 415 million people around the world [12]. With the increasing prevalence of diabetes, diabetic retinopathy (DR) is emerging as the leading cause of avoidable blindness worldwide [15].

One of the most widespread chronic diseases of our time is the diabetes posing not only threat to life of a patient, but also the factor influencing quality of life. Diabetes is accompanied by early disability, an invalidization, leads to development of heavy complications and decrease in resource stocks of the patient [4]. With the duration of the disease up to one year, 7,43 \% of patients already have diabetic complications; with the duration of diabetes up to $1-5$ years $-38,53 \%$; with the duration of diabetes up to $6-9$ years $-67,41 \%$; with the duration of diabetes up to 10 years or more $-84,2 \%$ have different complications of Type I diabetes. There are polyneuropathy $(19,41 \%)$, angiopathy $(15,71 \%)$, hepatosis $(14,35 \%)$, nephropathy $(10,26 \%)$, lipodystrophy $(9,16 \%)$, retinopathy $(5,49 \%)$ cataract $(1,94 \%)$ among the most common complications [8].

With increasing global prevalence of diabetes, DR is set to be the principle cause of vision impairment in many countries. DR affects a third of people with diabetes and the prevalence increases with duration of diabetes, hyperglycemia, and hypertension-the major risk factors for the onset and progression of DR. There are now increasing data on the epidemiology of diabetic macular edema (DME), an advanced complication of DR, with studies suggesting DME may affect up to $7 \%$ of people with diabetes [13].

We reviewed literature to provide an overview of emerging trends on the burden, epidemiology, risk factors, and prevention of DR. First, there is clear evidence of a global increase in the prevalence of diabetes. Second, there is a decline in the incidence of blindness due to DR, particularly in developed countries [16]. Third, DME rather than proliferative diabetic retinopathy (PDR) is the increasingly common cause of visual impairment. Fourth, DR awareness remains patchy and low in most populations. Fifth, hyperglycemia remains the most consistent risk factor for DR in type 1 diabetes across different studies and populations. Sixth, in contrast, blood pressure is an important risk factor for DR in type 2 diabetes. Seventh, the relationship between dyslipidemia and DR remains unclear, with inconsistent results from different studies and trials. Eighth, the utility of predictive models incorporating multiple risk factors for assessing DR risk requires evaluation. Ninth, photographic screening of DR using tele-ophthalmology platforms is increasingly recognized as being feasible and cost-effective. Finally, DR prevention in low-resource settings cannot follow models developed in high-resource countries and requires different strategies [17].

The analysis of literature shows that questions of studying of diabetes and diabetic retinopathy concern generally a somatic condition of patients with diabetes. The works devoted to an assessment of mentality at diabetes, very few, they have separate character, are insufficiently deep and systematized that is caused by complexity and a polymodality of a subject of studying. Besides, not enough attention is paid to a differentiation problem in a nosology of patients, including a role of different types of diabetes during and a disease outcome though it is proved that the psychological relations in many respects determine the potential of the personality and are her driving force [4].

Analysis of scientific research. Taking into consideration the psychological character of patients with diabetes mellitus, W. Menninger formulated the concept of a "specific personality" of a patient. According to I. Mirsky and F. Dunbar, diabetes mellitus patients have a specific personality structure, which differs from healthy people's one, and also differs from patients with other chronic diagnoses. F. Alexander suggested that "diabetes mellitus is not characterized by personality type, but by a typical conflict situation and the core of emotional conflict, which determine the somatic features while the disease" [1]. P. Benton, describing diabetes mellitus patients' traits of egocentrism, irritability, moodiness and restraint, noted the peculiarity that "intelligence and energy are more common features for diabetes mellitus people than for the average population" [3]. 
V. Vechkanov suggested that such psychological personality traits as sensitivity, emotional passivity and isolation provide the basis for the premorbid state of the disease. B. Tselibeev diagnosed adult patients; it was revealed that patients were often anxious, susceptible, sensitive and touchy before the disease. These traits intensified with the manifestation of the disease (diabetes mellitus) [2].

The increase in lifelessness, rapid fatigability, and asthenia are distinguished in patients with diabetes mellitus. Changes in behavior are manifested in indecision, inaction, as well as in the desire for solitude. The main protective psychological mechanism of diabetes mellitus patients is rationalization. In addition, the fixing of such traits as susceptibility, vulnerability, excitability, anxiety, a tendency towards frustration and fantasies, emotional instability begins. All these personality traits are poorly controlled by patients with diabetes [5].

Type II diabetes mellitus women are generally proactive and sociable. They accept criticism adequately, quickly forget about insults and offenses; they are neat and never focus on insults or criticism. They do not show special feelings for people, they can show empathy in special cases and rarely cry. Often they carry out tasks at work and at home carefully, try to maintain cleanliness everywhere. Women can speak to a large audience if it is necessary; however, they do not specifically draw attention to themselves, they do not avoid communication with people. They are proactive and emotionally mobile. They have a steady and even mood, expressed an average emotional susceptibility, most of them try to keep calm, are able to control their strong desires, deny their mood swings and present their behavior as stable and independent of external circumstances [5].

The mood of men with this pathology is often neutral; the coordination of movements and facial gesture are expressed at the level of average values. They adequately accept criticism, quickly forget about insults and offenses; they are neat, non-revenge, but they do not show special feelings for people; they are capable of empathic relations in special cases, rarely cry. Men agree to perform work that requires thoroughness at work and at home, try to maintain cleanliness if it is necessary. These persons deny their shyness, do not show initiative, are verbose and involved in various forms. They are able to control their desires and keep themselves cool, have a steady, even mood and average emotional sensitivity [5].

Thus, speaking about the differences in the character peculiarities of the individual and the assessment of health in men and women with diabetes mellitus, the main characteristics can be distinguished: communicative skills and talkativeness turned out to be more represented in women. However, they are more demonstrative and emotionally unstable; they are characterized by emotional outbursts and changes. Male respondents are more restrained and secretive, have an average emotional sensitivity, try to keep cooler, have a more stable mood [5].

However, these traits are presented in Type II diabetes mellitus patients, but not in diabetic retinopathy persons. Also, these features cannot indicate the emotional-volitional and motivational characteristics which are necessary for these persons to form compliance.

The purpose of the article is to study traits of patients with proliferative and nonproliferative stages of diabetic retinopathy.

Presentation of the main material and research results. An open controlled study, which was conducted at the Department of Ophthalmology, State Institution "Dnipropetrovsk Medical Academy of the Health Ministry of Ukraine", after obtaining informed consent, covered 30 patients with diabetic retinopathy (E 10.3, E 11.3): 12 patients with Type I diabetes mellitus and 18 patients with Type II diabetes mellitus (E 11). The diagnosis of cerebral diabetes was made in accordance with the recommendations of the Association of Endocrinologists of Ukraine and the European Society of Endocrinology [14]. The coding of the disease was carried out in accordance with the International Statistical Classification of Diseases and Related Health Problems (ICD-10) [7].

Type I diabetics were thoroughly examined at the official order of the Ministry of Health of Ukraine on December 29, 2014, No. 1021, "Unified clinical protocol of primary, urgent, and secondary (specialized) and tertiary (highly specialized) medical care. Type I diabetes mellitus in youth and adulthood" [9]. Type II diabetics underwent a thorough medical examination at the Ministry of Health of Ukraine on December 21, 2012, No. 1118 "Unified clinical protocol of primary and secondary (specialized) medical care. Type II diabetes mellitus [10]. Diagnosis of 
diabetic retinopathy and medical care were held according to the order of the Ministry of Health of Ukraine No. 356 of 22.05.2009 "Protocol of medical assistance to diabetic retinopathy patients" [6].

Among the examined patients, 20 individuals were diagnosed with non-proliferative stage of diabetic retinopathy, 10 individuals were diagnosed proliferative one.

Study design: criteria for inclusion in the research - diagnosis of diabetes mellitus Type I - II of moderate severity in the stage of subcompensation, manifestation of diabetes retinopathy, the presence of cataracts, the severity of the most optimal optics, and the absence of other problems; exclusion criteria - transition of diabetes mellitus to a severe stage or decompensation, cataract or dimming of the eye opticus, presence of the other retina disease or of the ophthalmic nerve.

The average values in the examined patients were: patients age - $61.3 \pm 3.8$; time after the making diagnosis of cerebral diabetes $-9.7 \pm 2.04$; the age when diabetic retinopathy was diagnosed $14.4 \pm 11.94$ years, respectively. There were 13 men and 17 women among all the patients. The groups were comparable and did not significantly differ in age or in gender.

Diabetic retinopathy individuals' traits are characterized by the method of R. Kettell [11].

The averaged characterological profiles of patients with non-proliferative and proliferative stages of diabetic retinopathy fit within the normal range and practically had neither low nor high marks.

All patients with retinopathy had the highest rates: $+\mathrm{E}$ (independence-subordination), $+\mathrm{L}$ (suspiciousness-credulity), + Q3 (high-low self-control), + O (anxiety-calmness), and the lowest: C (emotional stability), - F (concern-carelessness), - H (courage-timidity), - J (suppleness-rigidity), - Q1 (radicalism-conservatism), - Q4 (tension-relaxation).

Excessive self-conceit, suspicion, self-interests, a search for people's deficiency, jealousy, envy $(+\mathrm{L})$, insecurity, anxiety, depression, vulnerability, impressionability $(+\mathrm{O})$, discipline, accuracy in fulfilling social requirements, good control of emotions, concern for one's public reputation $(+\mathrm{Q} 3)$, optimal attitude to authorities $(+\mathrm{E})$, relaxation, lethargy, calm, low motivation, laziness, excessive satisfaction and unperturbation property (- Q4), conservatism, resistance to traditional difficulties, doubts about new ideas, a tendency to moralize and preaching (- Q1), low tolerance to stress factors, susceptibility to emotions, variability of interests, labiality of mood, irritability, fatigability, neurotic symptoms, hypochondria (- C), prudence, caution, prudence, silence, tendency to complicate things, some concern, pessimistic perception of reality, concern about the future, about worrying about failures (- the F), preference for staying in the shadow, narrow friendship, increased sensitivity to threat $(-\mathrm{N})$ were observed.

The most informative for assessing diabetic retinopathy patients' traits were such factors as $\mathrm{M}$ (practicality-impracticality), B (limited thinking-ingenuity), N (flexibility-straightforwardness), E (independence-subordination), Q1 (radicalism-conservatism), Q3 (high-low self-control), G (emotional stability), J (suppleness-rigidity), Q4 (tension-relaxation), H (courage-timidity).

Serious problems for these individuals were conservatism, doubts about new ideas (-Q1), skepticism, cynicism, pragmatism (-J); non-proliferative diabetic retinopathy patients' trait is an inability to interact with others $(+E)$, while proliferative diabetic retinopathy patients' traits are prudence, insight, a pragmatic approach to problems $(+\mathrm{N})$, restraint, pessimism $(+\mathrm{Q} 3)$ and the desire to introduce oneself "in a favorable position"(- MD).

The leading traits of all examined diabetic retinopathy patients were independence, suspicion, anxiety, uncertainty, concern, timidity, lack of motivation, self-confidence, conservatism and discipline.

Non-proliferative and proliferative diabetic retinopathy patients differed in some traits.

Non-proliferative and diabetic retinopathy patients had the highest rates: + F (preoccupation nonchalance), $+\mathrm{L}$ (suspiciousness-credulity), $+\mathrm{C}$ (emotional stability), + $\mathrm{E}$ (independencesubordination), + Q3 (high-low self-control) ; and the lowest ones were - J (suppleness-rigidity), Q1 (radicalism-conservatism), - Q4 (tension-relaxation), - A (sociability - isolation), - B (silo mentality - mental agility).

They had such traits as impulsiveness, carelessness, talkativeness; expansiveness, emotionality, dynamic communication $(+F)$; jealousy, envy, suspicion, high self-esteem, selfinterest, cautiousness in actions, self-centeredness $(+\mathrm{L})$; emotional maturity, endurance, realistic mood, consistency of interests, a certain insensibility $(+\mathrm{C})$; self-confidence, stubbornness, 
bordering on aggressiveness, independence in judgments and behavior, conflict, waywardness $(+$ E); developed self-control, accuracy of fulfilling social requirements $(+\mathrm{Q} 3)$; self-confidence, practicality, some rigidity, severity, callousness in relation to others (- J); conservatism, doubtful attitude to new ideas, a tendency to moralization and preachment (- Q1); lethargy, low motivation, laziness, excessive satisfaction and equanimity (- Q4); excessive rigor in assessing people, skepticism, love of loneliness (- A); concreteness and rigidity, and occasionally and emotional disorganization of thinking (- B).

Serious problems for these individuals were conservatism, doubts about new ideas (- Q1), skepticism, cynicism, pragmatism (- J); moderate (4.0 - 5.9 points) - isolation, distrust (- A), silo mentality, difficulties in mastering new material (- B), low motivation, laziness, equanimity (- Q4), a tendency to follow norms $(+G)$, desire to introduce oneself "in a favourable position" (-MD).

The leading traits of non-proliferative and diabetic retinopathy patients were carelessness, suspicion, independence, insensitivity, conflict, developed self-control, self-confidence, callousness, conservatism, low motivation, skepticism and rigidity of thinking.

Proliferative and diabetic retinopathy patients were inherent in: + L (suspicion-credulity), + E (independence-subordination), + Q3 (high-low self-control), + $\mathrm{O}$ (anxiety-calmness), $+\mathrm{G}$ (expressed strength "I" - unprincipled), - Q1 (radicalism-conservatism), - C (emotional stability), - J (suppleness-rigidity), - F (concern-carelessness).

They were distinguished by jealousy, envy, suspicion, high self-conceit, interest turned on themselves, caution in actions, self-centeredness $(+\mathrm{L})$; self-confidence, stubbornness, bordering on aggressiveness, independence of judgments and behavior, conflict, waywardness $(+E)$; developed self-control, the accuracy of fulfilling social requirements $(+\mathrm{Q} 3)$; conscious following norms and rules, accuracy, responsibility $(+\mathrm{G})$; conservatism, doubtful attitude to new ideas, a tendency to moralization and preachment (- Q1); self-confidence, practicality, some rigidity, severity, callousness in relation to others (- J); anxiety, depression, vulnerability, sensitivity $(+\mathrm{O})$; the variability of feelings and interests, a tendency to mood labiality, irritability, fatigue, neurotic symptoms, hypochondria (- C); concern, pessimism, expectation of failure (- F).

Serious problems for these individuals were conservatism, doubts about new ideas (- Q1); moderate ones (4.0 - 5.9 points) were isolation, distrust (- A), silo mentality, difficulties in mastering new material (- B), low tolerance to emotional factors, self-doubt, irritability, frequent manifestation of excitement (- C) increased caution, prudence, restraint, sometimes pessimism, severity (-F), shyness, timidity, caution, the desire to be overshadowed, the preference of a limited friendship $(-\mathrm{H})$, excessive self-confidence, subjectivity, hypertrophied desire for independence spine, stiffness, skepticism, sometimes cynicism, pragmatic (- J), low motivation, laziness, coolness (- Q4).

The leading traits of proliferative and diabetic retinopathy patients were suspicion, selfconfidence, developed self-control, responsibility, conservatism, self-confidence, anxiety, irritability and pessimism.

Thus, the distinctive traits of the non-proliferative and diabetic retinopathy patients were carelessness, consistency of interests, tension, isolation, rigidity of thinking; proliferative and diabetic retinopathy patients' traits were anxiety, responsibility, uncertainty and pessimism.

\section{Conclusions.}

1. All patients with diabetic retinopathy were characterized by the following traits: independence, suspicion, anxiety, uncertainty, concern, hard work, insufficient motivation, selfconfidence, conservatism, and discipline. The most serious of them were: conservatism, doubts about new ideas (- Q1), skepticism, cynicism, pragmatism (- J).

2. Non-proliferative diabetic retinopathy patients' traits were carelessness, suspicion, independence, insensitivity, conflict, developed self-control, self-confidence, callousness, conservatism, low motivation, skepticism, rigidity of thinking. The serious problems for these individuals were their conservatism, doubts about new ideas, skepticism, cynicism, pragmatism; the moderate ones were seclusion, distrust, silo mentality, difficulty in mastering new material, low motivation, laziness, ease, a tendency to comply with the rules, the desire to introduce oneself "in a favourable position". 
3. The leading traits of proliferative diabetic retinopathy people were suspicion, selfconfidence, developed self-control, responsibility, conservatism, self-confidence, anxiety, irritability and pessimism. Conservatism and doubts about new ideas were the most difficult problems for these individuals; the moderate ones are seclusion, distrust, silo mentality, difficulty in mastering new material, low tolerance for emotional factors, self-doubt, irritability, frequent manifestation of excitement, increased caution, discretion, restraint, sometimes pessimism desire to be in the shadows, preference for a narrow horn of close friends, excessive self-confidence, subjectivism, hypertrophied desire for independence, stubbornness, skepticism, sometimes cynicism, pragmatism, low motivation, laziness and ease.

Prospects for further research are the need to determine the impact of emotional, emotionalvolitional and intellectual characteristics of diabetic retinopathy patients and their impact on quality of life and the formation of compliance.

\section{Література}

1. Александер Ф. Психосоматическая медицина. Академия, 2000. 380 с.

2. Александровский Ю. А. Психические расстройства в общемедицинской практике и их лечение. М.: ГЭОТАР-МЕД,2004. 240 с.

3. Бентон П. С Психические аспекты при сахарном диабете. Диабет. Академия, 2000. 410 с.

4. Валиева Д. А. Психоэмоциональные особенности пациентов с сахарным диабетом. Вестник современной клинической медицины. 2014. Т. 7 (прилож. 1).

5. Денисова Е. А., Чугунова И. М. Характерологические особенности больных сахарным диабетом. Научно-методический электронный журнал «Концепт». 2017. Т. 2. С. 140-143. URL: http://e-koncept.ru/2017/570030.htm.

6. Додаток до наказу МОЗ України № 356 від 22.05. 2009 року «Протокол надання медичної допомоги хворим з діабетичною ретинопатією» (medstandart.net).

7. International Statistical Classification of Diseases and Related Health Problems (ICD-10) / classinform.ru

8. Статистика цукрового діабету у дітей України в таблицях і графіках. За ред. Н. Б. Зелінської. К.: РВХ «Ферзь», 2013. 16 с.

9. «Уніфікований клінічний протокол первинної, екстреної, вторинної (спеціалізованої) та третинної (високоспеціалізованої) медичної допомоги Цукровий діабет 1 типу у молодих людей та дорослих) Наказ МОЗ України від 29 грудня 2014 року № 1021 (mtd.dec.gov.ua).

10. «Уніфікований клінічний протокол первинної та вторинної (спеціалізованої) медичної допомоги Цукровий діабет 2 типу) Наказ МОЗ України від 21 грудня 2012 року № 1118 (mtd.dec.gov.ua).

11. 16 факторный личностный опросник Р. Б. Кеттелла (форма C). psycabi.net

12. American Diabetes Association. Diagnosis and Classification of Diabetes Mellitus. Diabetes Care. 2014. Vol. 37, S. 1.S.81-90. Doi.org/10.2337|dc14-S081

13. Ding J., Wong T. Current epidemiology of diabetic retinopathy and diabetic macular edema. Curr. Diab. Rep. 2012. 12 (4). S. 346-354. doi: 10.1007/s11892-012-0283-6.

14. European Society of Endocrinology . https: www.ese-hormones.org

15. Ophthalmic Epidemiol. 2016. 23(4). S. 209-222.

doi: 10.1080/09286586.2016.1193618. Epub 2016 Jun 29.

16. Bursell S. E., Fonda S. J., Lewis D. G., Horton M. B. Prevalence of diabetic retinopathy and diabetic macular edema in a primary care-based teleophthalmology program for American Indians and Alaskan Natives. PLoS One. 2018. 13(6) :e0198551. doi: 10.1371/journal.pone.0198551.

17. Sabanayagam C., Yip W. , Ting D., Tan G., Wong T. Ten Emerging Trends in the Epidemiology of Diabetic Retinopathy. Ophthalmic Epidemiol. 2016. 23 (4). S. 209-222. doi: 10.1080/09286586.2016.1193618. Epub 2016 Jun 29.

\section{References}

1. Alexander F. (2000). Psychosomatichesskaya medicina. Academia. 380 (rus).

2. Alexandrovskiy Y. A. (2004). Psychicheskiye rasstroystva v obshchemedicinskoy practice I ih lecheniye. M. GEOTAR-MED. 240 (rus). 
3. Benton P. S. (2000). Psychicheskiye aspecti pri sacharnom diabete. Diabet. Academia. 410 (rus).

4. Valiyeva D. A. (2014). Psychoemotzionalniye osobennosty patzientov s sacharnim diabetom. // Vestnic sovremennoy clinicheskoy medicine, 7, Prilozheniye 1. (rus).

5. Denisova E. A., Chugunova I. M. (2017). Characterologicheskie osobennosty bolnich sacharnim diabetom . Nauchnometodicheskiy electronniy zhurnal "Koncept", 2, P. 140-143. (rus). URL: http://e-koncept.ru/2017/570030.htm.

6. Dodatok do nakazy MOZ Ukraini № 356 vid 22.05. 2009 roku "Protocol

Nadanya medichnoyi dopomogi chvorim z diabetichnoy retinopatieyu". (ukr). medstandart.net.

7. International Statistical Classification of Diseases and Related Health Problems (ICD-10) / classinform.ru (eng).

8. Statistika zhukrovogo diabetu u ditey Ukraini v tablitzax I graficax. (2013). Za red. N. B. Zelinskoi. K. RVX Ferz. - 16. (ukr).

9. "Unificovaniy clinichniy protocol pervinniyi, extrennoyi, vtorinnoyi (specializovanoyi) ta tretinniyi (visokospecializovanoyi) medichnoyi dopomogi. Zhukroviy diabet 1 typu u molodich ludey ta doroslich. Nakaz MOZ Ukraini № 356 vid 22.12. 2014 roku № 1021. (ukr). mtd.dec.gov.ua 10. Unificovaniy clinichniy protocol pervinniyi, vtorinnoyi (specializovanoyi) medichnoyi dopomogi. Zhukroviy diabet II typu. Nakaz MOZ Ukraini № 1118 vid 21.12. 2012 roku № 1021. (ukr). mtd.dec.gov.ua

11. 16 factorniy lichnostniy oprosnic R. B. Kettella (forma C). (rus). psycabi.net

12. American Diabetes Association. Diagnosis and Classification of Diabetes Mellitus. Diabetes Care. 2014. Vol. 37, (Supplement 1). S. 81-S. 90. Doi.org/10.2337|dc14-S081

13. Ding J., Wong T. Current epidemiology of diabetic retinopathy and diabetic macular edema. Curr. Diab. Rep. 2012. 12(4). S. 346-354. doi: 10.1007/s11892-012-0283-6.

14. European Society of Endocrinology / https: www.ese-hormones.org

15. Ophthalmic Epidemiol. 2016. 23(4). S. 209-222. doi: 10.1080/09286586.2016.1193618. Epub 2016 Jun 29.

16. Bursell S. E., Fonda S. J., Lewis D. G., Horton M. B. Prevalence of diabetic retinopathy and diabetic macular edema in a primary care-based teleophthalmology program for American Indians and Alaskan Natives. PLoS One. 2018. 13(6):e0198551. doi: 10.1371/journal.pone.0198551.

17. Sabanayagam C., Yip W. , Ting D., Tan G, Wong T. Ten Emerging Trends in the Epidemiology of Diabetic Retinopathy. Ophthalmic Epidemiol. 2016. 23(4). 209-222. doi: 10.1080/09286586.2016.1193618. Epub 2016 Jun 29. 